JIKAP PGSD: Jurnal IImiah Ilmu Kependidikan

Vol,1. No,2. Tahun 2017

e-ISSN: 2597-4440 dan p-ISSN: 2597-4424

This work is licensed under a Creative Commons Attribution

4.0 International License

\title{
Pengaruh Penerapan Supervisi Akademik Berbasis Modeling Inspiratif Terhadap Peningkatan Kemampuan Mengajar Guru SD Gugus IV Kecamatan Makassar Kota Makassar
}

\author{
Tamrin \\ Pengawas Satuan Pendidikan Dikdas Kota Makassar \\ Email: thamrinpaelori06@gmail.com.
}

\begin{abstract}
Abstrak. Penelitian ini bertujuan mendeskripsikan pengaruh penerapan gerakan satu guru satu inovasi dengan pendekatan inspiratif bagi guru SD gugus IV Kecamatan Makassar Kota Makassar yang secara khusus berkaitan dengan (1) Pengaruh supervisi akademik berbasis modeling inspiratif terhadap peningkatan kemampuan mengajar guru SD pada gugus IV Kecamatan Makassar Kota Makassar. (2) Respon guru terhadap supervisi akademik berbasis modeling inspiratif di SD gugus IV Kecamatan Makassar Kota Makassar. Metode penelitian ini adalah eksperimen semu dengan desain pra dan post yang menggunakan subjek penelitian sebanyak 62 orang guru sekolah binaan. Analisis hasil penelitian menhggunakan statistic inferensial atas uji.t (t.tes) yang dilaksanakan terhadap guru SD pada gugus IV Kecamatan Makassar, Kota Makassar pada tahun pelajaran 2016/2017. Hasil penelitian menunjukkan bahwa ada pengaruh signifikan penerapan supervisi akademik berbasis modeling inspiratif terhdapat peningkatan kemampuan mengajar guru. Hal ini terlihat pada nilai signifikansi lebih kecil daripada $(0,00<0,05)$ yang artinya $\mathrm{H}_{1}$ (artinya ada pengaruh signifikan penerapan supervisi akademik berbasis modeling inspiratif terhadap peningkatan kemampuan mengajar guru SD pada gugus IV Kecamatan Makassar Kota Makassar diterima. Selain itu, respon guru terhdap penerapan supervisi akademik berbasis modeling inspiratif sangat positif.
\end{abstract}

Kata kunci: supervisi akademik, modeling inspiratif, dan kemampuan mengajar

\begin{abstract}
This study aims to describe the effect of the application of one teacher movement of an innovation with an inspirational approach for elementary school teachers group IV Makassar Makassar subdistrict specifically relates to (1) Influence of inspirational model based supervision supervision on the improvement of teaching skills of elementary school teachers in cluster IV Makassar District Kota Makassar . (2) Teacher's response to inspirational model inspirational-based supervision in elementary school of group IV Makassar sub-district of Makassar City. The method of this research is quasi experiment with pre and post design using research subject as many as 62 teachers of target schools. Analysis of research result using inferential statistic on test.t (t.tes) conducted on elementary school teacher in group IV of Makassar Sub-district, Makassar City in academic year 2016/2017. The results showed that there is a significant influence on the application of inspirational modeling based academic supervision on improving teachers' teaching ability. This is seen in the significance value less than $(0.00<0.05)$ which means $\mathrm{H} 1$ (meaning there is a significant influence on the application of inspirational modeling based academic supervision on the improvement of teaching ability of elementary school teachers in group IV Makassar District Makassar City is accepted.In addition, teacher's response to the application of inspirational modeling based academic supervision is very positive.
\end{abstract}

Keywords: academic supervision, inspirational modeling, and teaching skills 


\section{PENDAHULUAN}

Peran guru sangat strategis dalam dunia pendidikan. Undang Undang Nomor 14 tahun 2005 pasal 4 mengamanatkan bahwa kedudukan guru sebagai tenaga professional berfungsi untuk meningkatkan martabat dan peran guru sebagai agen pembelajaran berfungsi untuk meningkatkan mutu pendidikan nasional. Sebagai agen pembelajaran (learning agent) guru berperan sebagai fasilitator, motivator, pemacu, perekayasa pembelajaran, dan pemberi inspirasi.

Mencermati peran guru sebagai agen pembelajaran yang diamanatkan dalam undangundang tersebut, tentu bukan pekerjaan mudah. Untuk itu, guru harus memiliki kemampuan mengajar atau melaksankan pembelajaran yang memadai. Tanpa kemampuan mengajar guru yang memadai maka akan sulit mewujudkan efektivitas pembelajaran, sehingga pencapaian tujuan pembelajaran pun tidak maksimal. Masalahnya, kenyataan menunjukkan bahwa kompetensi guru dalam pembelajaran atau kemampuan mengajar sangat bervariasi. Dapat diyakini bahwa masih banyak guru mempunyai kemampuan mengajar rendah. Hasil uji kompetensi guru (UKG) 2015 semua mata pelajaran, rata-rata hanya 53,02 di bawah standar rata-rata 55 yang ditetapkan. Rata-rata kompetensi professional 54,77, sementara nilai rata-rata kompetensi pendagogik 48,94. Dalam skala kecil, hasil supervisi terpadu bagi guru sekolah dasar di Kota Makassar tahun 2016 menunjukkan bahwa $37 \%$ dari seluruh jumlah guru sekolah dasar yang disupervisi menunjukkan kualitas kemampuan melakukan pembelajaran kategori sangat rendah.

Tentu saja guru seperti di atas tidak bisa memerankan peran sebagai agen pembelajaran secara baik sesuai amanat undang-undang. Jika hal ini dibiarkan, tentu kualitas kinerja guru dalam pembelajaran tidak dapat diharapkan. Akibatnya, mutu hasil pembelajaran di sekolah tidak memadai. Oleh karena itu, kompetensi guru harus dikembangkan. Salah satu upaya strategis adalah pembinaan profesional melalui supervisi secara kontinyu. Mengharapkan pelatihan, workshop, simposium, atau seminar, dan sejenisnya bagi guru tentu sangat terbatas. Kemapuan pemerintah untuk mengembangkan kompetensi mereka melalui pelatihan sangat terbatas, karena faktor biaya. Demikian halnya dengan upaya pribadi para guru dalam mengembangkan kompetensi mereka dalam pembelajaran juga belum menjadi budaya. Survei terhadap beberapa guru sekolah dasar di Makassar menunjukkan bahwa masih banyak guru yang sangat jarang mengikuti kegiatan pengembangan profesional pelatihan dan seminar. Beberapa responden mengatakan dalam enam tahun hanya satu sampai dua kali mengikuti pelatihan, bahkan ada hanya sekali mengikuti seminar dalam 10 tahun karir guru.

Berdasarkan uraian di atas, maka supervisi merupakan upaya yang strategis dalam membantu meningkatkan kompetensi guru. Hasil penelitian yang dilakukan oleh Syukri (2012) Ruhayati, 2013, Junaid (2011), Setiyono (2013), dan Amani (2013) menunjukkan peran supervisi sangat menentukan kualitas pembejalaran. Demikian pula Komariah (2011), Goldhammer (1999), dan Gurnam (2012) mengemukakan bahwa supervisi sangat diperlukan tetapi perlu adanya model dan strategi yang inovatif dalam pelaksanaan supervisi pembelajaran untuk membantu guru dalam pelaksanaan tugasnya. Hal ini menunjukkan bahwa supervisi sangat penting dalam upaya peningkatan kemampuan mengajar guru, namun banyak guru yang kurang menyukai kegiatan supervisi. Ketidaksukaan guru disupervisi pada umumnya karena supervisi selama ini cenderung berdampak psikologis kepada mereka. Guru merasa tidak terbantu, bahkan ada kecenderungan supervisi menjadi beban. Selama ini supervisi masih sering tidak menyelesaikan masalah secara efektif karena metode atau strateginya kurang efektif. Balikan atau refleksi dalam supervisi masih dominan bersifat pengarahan bahkan instruktif, bukan melalui pemberian contoh atau model yang baik.

Fenomena yang berkembang selama ini, khususnya guru di sekolah dasar cenderung menuntut contoh dalam penyelesaian masalah, terutama guru yang mempunyai kemampuan melaksankan pembelajaran rendah. Guru dalam berbagai pelatihan atau workshop cenderung lebih menyukai contoh daripada pemaparan konsep. Metode pengarahan, instruksi, pemaparan konsep tampaknya kurang efektif meningkatkan kemampuan melaksankan pembelajaran guru di sekolah dasar. Jika materi pelatihan atau bimbingan teknis berkaitan dengan konsep, guru sangat mudah memahami, tetepi jika diharapkan mensimulasikan sangat banyak guru yang menghadapi kendala. Guru 
selalu mengharapkan contoh perilaku yang harus ditampilkan dalam melakukan aktivitas mengajar. Selain itu, kenyataan menunjukkan bahwa kompetensi pengawas dalam dalam mata pelajaran tidak merata dari setiap mata pelajaran sehingga memungkinkan supervisi akademik kurang efektif atau mengalami kendala, sehingga bantuan model dari guru yang terampil sangat dibutuhkan.

Berdasarkan uraian di atas, maka alternatif pemecahan masalahnya adalah menggunakan metode supervisi akademik berbasis modeling inspiratif. Hal ini dirancang karena kemampuan mengajar guru membutuhkan inspirasi dan support dalam bentuk modeling atau contoh yang baik sebagai suatu metode supervisi. Pembelajaran, sebagai sebuah keterampilan, membutuhkan latihan yang dapat mengubah prilaku guru dalam pembelajaran. Konsep yang dipahami guru tentang mengajar mungkin sudah cukup. Namun, dibutuhkan penguasaan praktis dalam implementasinya melalui latihan dengan contoh. Sebagaimana asumsi umum bahwa dalam keterampilan, tidak selamanya pemahaman teori sejalan dengan kemampuan mempraktikkannya, ternyata sangat tepat bagi kondisi kemampuan guru dalam melaksankan mepembelajaran. Oleh karena itu, penulis mendesain metode supervisi akademik yang berbasis modeling yakni memanfaatkan guru atau teman sejawat yang mempunyai kemampuan mengajar yang memadai sebagai model yang dapat diinspirasi dalam melaksanakan kegiatan pembelajaran. Metode supervisi berbasis modeling inspiratif ini dilandasi oleh teori belajar sosial (social learning theory) yang dipelopori oleh Albert Bandura bahwa sebagian besar tingkah laku manusia dipelajari melalui peniruan maupun penyajian pemodelan. Orang lebih mudah melakukan sesuatu berdasarkan model daripada pemahaman yang dia tahu.

Berdasarkan uraian di atas, maka masalah yang dibahas dalam penelitian ini adalah menjawab pertanyaan (1) Apakah supervisi akademik berbasis modeling inspiratif berpengaruh terhadap peningkatan kemampuan mengajar guru SD pada gugus IV Kecamatan Makassar Kota Makassar? (2) Bagaimanakah respon guru terhadap supervisi akademik berbasis modeling inspiratif di SD gugus IV Kecamatan Makassar Kota Makassar?

\section{KAJIAN TEORI}

\section{Supervisi Akademik Berbasis Modeling Inspiratif}

Supervisi akademik berbasis modeling inspiratif dilandasi social learning theory atau teori belajar sosial yang dipelopori oleh Albert Bandura yakni salah satu konsep dalam aliran behaviorisme yang menekankan pada komponen kognitif dari pikiran, pemahaman dan evaluasi melalui peniruan atau pemodelan/modeling. Albert Bandura menyatakan: "Learning would be exceedingly labrious, not to mention hazardous, if people had to rely solely on the effects of their own actions to inform them what to do. Fortunately, most human behavior is learned observationally through modeling: from observing others one forms an idea of how new behaviors are performed, and on later occasions this coded information serves as a guide for action." (Rachel , 2013 dalam http://prezi.com) Intinya adalah: "Belajar akan sangat melelahkan dan berbahaya, jika orang mengandalkan efek dari tindakan mereka sendiri untuk memberitahu apa yang harus dilakukan. Sesungguhnya, sebagian besar perilaku manusia dipelajari melalui observasi modeling . Mengamati orang lain, satu bentuk gagasan tentang bagaimana perilaku baru dilakukan, dan pada kesempatan kemudian informasi ini berfungsi sebagai panduan untuk bertindak."

Menurut teori ini, faktor yang memainkan peranan penting adalah efikasi diri (self-efficasy). Efikasi diri sebagai keyakinan pada kemampuan diri sendiri untuk menghadapi dan memecahkan masalah dengan efektif. Efikasi diri berarti meyakini diri sendiri mampu berhasil dan sukses. Individu yang memiliki efikasi diri tinggi memiliki komitmen dalam memecahkan masalahnya dan tidak akan menyerah ketika menemukan bahwa strategi yang sedang digunakan itu tidak berhasil. Kesemua itu adalah menginspirasi keberhasilan individu lainnya sehngga menjadi kekuatan dalam dirnya. Individu yang memiliki efikasi diri yang tinggi akan sangat mudah dalam menghadapi tantangan. Individu tidak merasa ragu karena ia memiliki kepercayaan yang 
penuh dengan kemampuan dirinya. Individu terus tertantanga untuk melalukuan yang terbaik.

Bandura menyatakan proses mengamati dan meniru dan menginpirasi perilaku dan sikap orang lain sebagai model merupakan tindakan belajar efektif. Teori Bandura menjelaskan perilaku manusia dalam konteks interaksi timbal balik yang berkesinambungan antara kognitif, perilaku dan pengaruh lingkungan. Teori pembelajaran sosial ini dikembangkan dan menerima sebagian besar dari prinsip-prinsip teori-teori belajar perilaku, tetapi memberikan lebih banyak penekanan pada kesan dan isyaratisyarat perubahan perilaku, dan pada proses mental internal melalui peniruan. Menurut Bandura, dalam Dzaki (2011:21) menyatakan "sebagian besar manusia belajar melalui pengamatan secara selektif dan mengingat tingkah laku orang lain. Inti dari pembelajaran sosial adalah pemodelan (modeling)".

Pembelajaran melalui pengamatan antara lain (1) pembelajaran melalui pengamatan dapat terjadi melalui kondisi yang dialami orang lain, (2) pembelajaran melalui pengamatan meniru perilaku model meskipun model itu tidak mendapatkan penguatan positif atau penguatan negatif saat mengamati itu sedang memperhatikan model itu mendemonstrasikan sesuatu yang ingin dipelajari oleh pengamat. Neil Miller dan John Dollard dalam (Dahar, 2012).dalam laporan hasil eksperimennya mengatakan bahwa peniruan merupakan hasil proses pembelajaran yang ditiru dari orang lain. Proses belajar tersebut dinamakan "social learning"-"pembelajaran sosial". Perilaku peniruan manusia terjadi karena manusia merasa telah memperoleh tambahan ketika meniru orang lain. Olehnya, model memainkan peranan penting untuk menjadi sumber perubahan prilaku seseorang.

Teori ini menganut prinsip bahwa cara belajar yang baik adalah menginspirasi, mencontoh, dan mengkreasi model yang dilihat sebagai hasil belajar. Jika dilihat beberapa teknik supervisi yang lazim dilakukan, maka beberapa teknik dikembangkan sangat relevan dengan social learning theory. pada relitas supervisi menurut umumnya dilakukan beberapa macam kegiatan, yaitu observasi kelas, percakapan individu/kelompok, saling berkunjung, diskusi, rapat guru, kunjungan studi. Jlka dilihat dari jenis supervisi, Sahertian (2011) membedakan teknik supervisi menjadi dua yaitu teknik supervisi yang bersifat individual dan kelompok. Teknik supervisi yang bersifat individual ada tiga jenis yaitu: (1) kunjungan kelas, (2) Observasi, (3) percakapan pribadi. Teknik yang bersifat kelompok antara lain: rapat guru, diskusi kelompok, lokakarya, seminar, simposium, dan sebagainya. Teori ini relevan dengan hakikat supervisi akademik. Supervisi akademik yakni upaya memberikan layanan dan bantuan kepada guru-guru baik secara individual maupun secara kelompok dalam usaha memperbaiki pengajaran. Atau dengan kata lain rangsangan, bimbingan atau bantuan yang diberikan kepada guru-guru agar kemampuan profesional makin berkembang, sehingga situasi belajar semakin efektif dan efisien. Purwanto (2013), mengemukakan "supervisi adalah suatu aktivitas pembinaan yang direncanakan untuk membantu para guru dan pegawai sekolah lainya dalam melakukan pekerjaan secara efektif". Linda (2011:14) menyatakan "supervisi merupakan salah satu bagian dari manajemen personal pendidikan." Lebih lanjut ditegaskan bahwa guru memiliki kemampuan menjadi penanggungjawab professional dan lebih dari pada itu ia mampu menjadi "penganalisis kinerjanya sendiri, terbuka untuk membantu orang lain, dan mengarahkan diri sendiri" Unruh dan Turner (2011) menyatakan bahwa supervisi sebagai "sebuah proses sosial dari stimulasi, pengasuhan, dan memprediksi pengembangan professional guru" dan pengawas sebagai "penggerak utama".

Tentu saja kesemua itu harus menggunakan pendekatan pendekatan inspiratif. hal ini memungkinkan karena hakikat inspirasi adalah konadisi secara istimewa mendatangkan berbagai bentuk prilaku yang muncul karena individu suatu penerangan dalam pikiran dan hati sehingga dapat mengubah prilaku yang mendatangkan aktivitas karya yang lebih baik. berkat dorongan atau kekuatan inspiratif yang diperoleh dalam diri individu seorang akan mampu memusatkan kekuatan rohaniah pada apa yang ia kerjakan. Pemusatan perhatian, motivasi yang tinggi menjadikan seseorang produktif. Oleh karena itu, inspirasi merupakan ilham untuk melakukan yang terbaik. Inspirasi adalah sebuah tujuan dalam kehidupan yang akan membawa manusia pada suatu motivasi dan kebahagiaan tersendiri dalam kehidupanya.

\section{Penerapan Supervisi Akdemik Berbasis Modeling Inspiratif \\ a. Rasional}


Supervisi akademik berbasis modeling inspiratif ini dilandasi pemikiran bahwa guru lebih mudah mengembangakan sesuatu dalam pembelajaran melalui contoh sebagai inspirasi. Hal ini juga telihat para prilaku guru dalam mengembangkan kapasitas siswa. Guru selalu berorientasi pada contoh sebelum murid mengembangkan, mengkreasi, atau mengerjakan sesuatu. Inilah yang dianut guru dalam pembelajaran sehingga proses belajar guru juga mengedepankan contoh. Tentu saja ini sesuai dengan teori belajar sosial oleh Albert Bandura. Pemodelan ini merupakan cara mudah bagi guru dalam menginspirasi, memotivasi, dan mengefikasi diri. Tahapan pelaksanaan supervisi akademik berbasis modeling inspiratif memberi peluang kepada guru untuk terbantu dalam hal kemampuan mengajar mulai dari identifikasi kesulitan, bantuan melalui model, dan pengembangan kapasitas diri melalui efikasi sampai pada refleksi diri dan perayaan keyakinan keberhasilan merupakan tahapan yang mudah dan menarik bagi guru. Sebahagian dari proses ini juga merupakan suatu bentuk choaching terhadap peningkatan keterampilan guru dalam pembelajaran. Guru tidak terbebani lagi oleh cara supervisi sebagaimana yang selama ini berkembang. Guru memiliki motivasi kuat untuk mengembangkan kapasitasnya melalui sinergitas supervisor dan guru model. Hal ini karena supervisor dan guru model menunjukkan komitmen kuat dalam membantu para guru yang disupervisi. Selain itu, guru model secara tidak langsung juga sedang melakukan pengayaan berkaitan dengan pelaksanaan pembelajaran.

Supervisi akademik bebasis pemodelan menganut prinsip supervisi klinis kolaboratif antara lain (1) supervisor bertindak sebagai mitra atau guru yang disupervisi (spervee), (2) mempunyai derajat keahlian yang sama, (3) pendekatan yang digunakan adalah pendekatan inkuiri (mencoba menemukan dan memahami apa yang dilakukan supervee) (4) supervisi bertujuan untuk membantu mengembangkan kemampuan mengajar guru melalui kegiatankegiatan reflektif. Focus utama pada supervee dan dilakukan dengan realisasi kolegial yang sederajat dan interaktif serta demokratis.

\section{Perencanaan supervisi akademik berbasis modeling inspiratif}

Langkah awal dari supervisi akademik berbasis modeling inspiratif adalah melakukan perencanaan yang matang. Secara umum hal yang harus dilakukan adalah sebagai berikut:

a. Identifikasi masalah atau kemampuan guru dalam pembelajaran.

b. Menyiapkan instrumen supevisi akademik

c. Menentukan guru model berdasarkan mata pelajaran (termasuk supervisor dapat menjadi model sesuai keahliannya)

d. Melakukan kordinasi dengan kepala sekolah dan guru yang akan disupervisi

e. Menetapkan waktu supervisi kesepahaman/kesepakatan bantuan yang akan dilakukan sebagai bentuk kontrak antara supervisor dan supervee

f. Membuat persuratan sebagai prosedur pemanfaatan guru model

\section{Pelaksanaan supervisi akademik berbasis modeling inspiratif}

Secara operasional metode supervisi akademik berbasis modeling inspiratif dilakukan dengan tahapan sebagai berikut:

\begin{tabular}{lll}
\hline \multirow{2}{*}{ TAHAPAN } & \multicolumn{1}{c}{ DESKRIPSI KEGIATAN } & $\begin{array}{c}\text { ALAT } \\
\text { DAN } \\
\text { BAHAN }\end{array}$ \\
\hline $\begin{array}{l}\text { Observasi } \\
\text { Pembelajar }\end{array}$ an & $\begin{array}{l}\text { Observasi proses pembelajaran bagi guru yang disupervisi } \\
\text { (supervee) dilakukan bersama oleh supervisor dengan dengan guru } \\
\text { model. Pada tahap ini peran supervisor dan guru model sama yakni }\end{array}$ & $\begin{array}{c}\text { kamera } \\
\text { memotret secara utuh proses pembelajaran yang terjadi baik } \\
\text { video }\end{array}$ \\
& $\begin{array}{l}\text { kelemahan dan kelebihannya. Kegiatan observasi atau pengamatan } \\
\text { menggunakan intsrumen proses pembelelajaran dan desain RPP. }\end{array}$ \\
& $\begin{array}{l}\text { Proses ini dapat pula dilakukan dengan menggunakan alat perkam } \\
\text { berupa kamera video, sehingga dalam refleksi dapat dilihat (diputar }\end{array}$ & \\
& ulang) secara bersama-sama. Sifat pengatan ini harus dikondisikan \\
& oleh supervisor dan guru model sebagai bagian dari tim kolaborasi & \\
\hline
\end{tabular}




\begin{tabular}{|c|c|c|}
\hline \multirow{2}{*}{ Refleksi } & yang saling bertanggungj jawab atas keberhasilan pembelajaran. & \\
\hline & $\begin{array}{l}\text { Refleksi proses pembelajaran dilakukan secara kolegal bertiga } \\
\text { (supervee, supervisor dan guru model). Dalam refleksi ini diskusi } \\
\text { dilakukan lebih menekankan pada upaya merefleksi diri supervee } \\
\text { dengan menggali apa yang dikerjakannya terhadap kelebihan dan } \\
\text { kelemahan, serta menegaskan/ menye-pakatinya. Kelemahan } \\
\text { kelebihan supervee sedapat mungkin ditemukan dan disadari sendiri } \\
\text { olehnya sehigga supervee tidak merasa dinilai tetapi benar-benar } \\
\text { merasa akan dibantu. Jika supervee sulit menemukan kelemahan } \\
\text { pembelajarannya maka super-visor mendorong supervee untuk } \\
\text { menemu-kannya melalui pertanyaan-pertanyaan yang bersifat } \\
\text { reflekstif. Contoh: Menurut Ibu/ Bapak bagaimana tahapan } \\
\text { kegiatan apakah siswa sudah mendominasi kegiatan? Jika belum } \\
\text { disepahami maka dikatanyakan lagi unsur-unsur pada hal tersebut. } \\
\text { Misalnya: Bagaimana menurut Ibu/Bapak sewaktu anak berdiskusi } \\
\text { ketuanya sangat hebat tetapi ada dua anak lebih banyak diam?, dan } \\
\text { seterusnya sampai guru tersebut memahami kelemahan itu sendiri. } \\
\text { Tentu hal ini disepahami secara baik sehingga tidak merasa itu } \\
\text { sebagai sesuatu yang negatif tetapi merupakan hal yang akan } \\
\text { dikembangkan bersama nanti. Hindari menunjukkan kesalahan } \\
\text { apalagi menggurui. Pernyataan seperti: sudah baik tetapi perlu } \\
\text { diperbaiki juga dianggap masih tidak kondusif. Oleh karena itu, } \\
\text { jalan keluar atau solusi dari kelemahan-kelemahan harus dipastikan } \\
\text { sebagai bentuk yang dipikirkan dan ditemukan sendiri oleh } \\
\text { supervee. Supervisor atau guru model hanya membantu guru } \\
\text { menemukan sensiri solusi-solusi dari masalahnya. Dengan } \\
\text { demikian, supervee mengembangkan kapasitasnya sendiri secara } \\
\text { sistematis, tidak menunggu bantuan, saran, atau instruksi yang akan } \\
\text { dilaksanakan. Jika supervee mengalami hambatan dalam } \\
\text { menemukan solusi-solusi maka dilakukan pola seperti dalam } \\
\text { menemukan hambatan. Pertanyaan-pertanyaan alternatif menjadi } \\
\text { bagian penting untuk menemukan solusi-solusi dari kelemahan } \\
\text { supervee. }\end{array}$ & $\begin{array}{l}\text { Catatan/ } \\
\text { hasil } \\
\text { pemot- } \\
\text { retan atau } \\
\text { hasil } \\
\text { rekaman }\end{array}$ \\
\hline $\begin{array}{l}\text { Desain } \\
\text { pembelajar } \\
\text { an I }\end{array}$ & $\begin{array}{l}\text { Setelah temuan-temuan disepahami dan ditemukan jalan keluarnya, } \\
\text { maka untuk membangun kemampuan guru dalam kelemahan- } \\
\text { kelemahan yang ada sebagai bentuk pengembangan guru/supervee, } \\
\text { maka supervee mendesain pembelajaran atau membuat persiapan } \\
\text { (RPP) secara kolaboratif dengan antara supervisor, guru model dan } \\
\text { sepervee. Pada tahap ini supervee tetap menjadi fokus, sehingga } \\
\text { seluruh kegiatan dikerjakan oleh supervee atas pandangan/ bantuan/ } \\
\text { bimbingan/arahan/coaching dari supervisor dan guru model. Sama } \\
\text { halnya pada tahap refleksi, supervee dibantu dengan } \\
\text { mengembangkan kemampuannya. Semua rumusan harus dipikirkan } \\
\text { dan ditentukan oleh sendiri supervee berdasarkan kesepahaman } \\
\text { supervisor maupun guru model. Kesulitan dalam merumuskan } \\
\text { desain RPP, dibantu dengan pola yang sama dengan identifikasi } \\
\text { temuan dalam refleksi sehingga desain RPP benar-benar ciptaan } \\
\text { supervee atas kolaborasi supervisor dan guru model. Proses desain } \\
\text { ini menggunakan contoh karya guru model sebagai dasar } \\
\text { pertimbangan, serta inspirasi dalam mengkreasi desain RPP yang } \\
\text { dibuat. Setelah desain RPP selesai secara lengkap, maka supervee } \\
\text { diminta menjelaskan bagimana mengimplentasikan RPP tersebut } \\
\text { dan disepahami oleh supervisor dan guru model. }\end{array}$ & $\begin{array}{l}\text { Silabus, } \\
\text { standar isi } \\
\text { bahan/ } \\
\text { materi ajar } \\
\text { dan RPP } \\
\text { model }\end{array}$ \\
\hline $\begin{array}{l}\text { Pelaksanaa } \\
\text { n modeling }\end{array}$ & $\begin{array}{l}\text { Pertemuan selanjutnya, guru model melakukan modeling (mengajar } \\
\text { di kelas supervee). Hal ini dapat dilakukan sendiri oleh supervisor }\end{array}$ & $\begin{array}{l}\text { Instrument } \\
\text { dan atau }\end{array}$ \\
\hline
\end{tabular}




\begin{tabular}{|c|c|c|}
\hline & $\begin{array}{l}\text { jika penguasaan materi mata pelajaran tersebut sangat memadai } \\
\text { (dapat dijadikan contoh). Supervisor dan supervee menjadi } \\
\text { pengamat pembelajajran. Pada tahap ini, supervee memotret secara } \\
\text { utuh kegiatan menggunakan instrumen sebagai-mana kegiatan } \\
\text { observasi dirinya. Supervisor lebih banyak berperan membantu } \\
\text { guru supervee dalam melihat kelebihan dan kelemahan yang akan } \\
\text { menjadi bahan refleksi untuk supervee. }\end{array}$ & $\begin{array}{l}\text { kamera } \\
\text { video }\end{array}$ \\
\hline $\begin{array}{l}\text { Refleksi } \\
\text { Modeling }\end{array}$ & $\begin{array}{l}\text { Tahap selanjutnya adalah refleksi terhadap modeling pembelajaran. } \\
\text { Pada tahap ini supervee menjadi fokus sehingga modeling } \\
\text { dijadikan bahan untuk mengembangkan pemahaman dan inspirasi } \\
\text { bagi supervee. Oleh karena itu, supervisor berfungsi sebagai } \\
\text { fasilitator dalam pemahaman unsur dalam pada modeling . } \\
\text { Supervee diminta mengungkapkan kelemahan dan kelebihan } \\
\text { modeling oleh guru model. Jika supervee tidak mampu atau tidak } \\
\text { mengungkap secara keseluruhan maka pola pada refleksi terda-hulu } \\
\text { digunakan. Supervisor mendorong supervee untuk menemukan } \\
\text { kelemahan dan kelebihan melalui pertanyaan reflektif. Demikian } \\
\text { halnya solusi-solusi jika ada, diupayakan oleh supervee atas } \\
\text { dorongan supervisor. Pola pertanyaan reflekstif juga digunakan } \\
\text { untuk menemukan solusi ini. Dengan demikian, proses modeling } \\
\text { menjadi bagian penting bagi supervee baik sebagai contoh inspirasi } \\
\text { dalam mengajar, bahan pembelajaran dalam kegiatan pembelajaran, } \\
\text { juga menjadi motivasi dan efikasi diri supervee melakukan yang } \\
\text { terbaik. }\end{array}$ & $\begin{array}{l}\text { Catatan/ } \\
\text { hasil } \\
\text { pemot- } \\
\text { retan atau } \\
\text { hasil } \\
\text { rekaman }\end{array}$ \\
\hline $\begin{array}{l}\text { Desain } \\
\text { pembelajar } \\
\text { an II }\end{array}$ & $\begin{array}{l}\text { Setelah diskusi dalam bentuk refleksi modeling untuk menguatkan } \\
\text { kemampuan guru dalam pemahaman pembelajaran yang baik maka } \\
\text { supervee mendesain pembel-ajaran (RPP) secara kolaboratif dengan } \\
\text { antara supervisor, guru model untuk dilakukan secara mandiri pada } \\
\text { pertemuan berikutnya. Pada tahap ini, prosesdesain pembelajaran I } \\
\text { sama. Supervee tetap menjadi fokus dan intervensi lebih dikurangi } \\
\text { dan penguatan kapasitas lebih ditingkatkan. Setelah desain selesai } \\
\text { dan disepahami, supervisor melakukan penguatan atau } \\
\text { menyemangati supervee dalam melaksana-kan pembelajaran yang } \\
\text { akan datang. }\end{array}$ & $\begin{array}{l}\text { Silabus, } \\
\text { standar isi } \\
\text { bahan/ } \\
\text { materi ajar } \\
\text { dan RPP } \\
\text { mode }\end{array}$ \\
\hline $\begin{array}{l}\text { Pembelajar } \\
\text { an Mandiri }\end{array}$ & $\begin{array}{l}\text { Tahap berikutnya supervee melakukan kegiatan pembelajaran } \\
\text { mandiri tidak lagi oleh guru model, melainkan hanya supervisor. } \\
\text { Peran supervisor adalah pengamat yang lebih bersifat kolaborator } \\
\text { dalam pembel-ajaran. Selain bertugas memotret kegiatan, juga } \\
\text { membantu supervee dalam melaksana-kan pembelajaran dengan } \\
\text { baik. }\end{array}$ & $\begin{array}{l}\text { Instrument } \\
\text { dan atau } \\
\text { kamera } \\
\text { video }\end{array}$ \\
\hline $\begin{array}{l}\text { Refleksi } \\
\text { Pembelajar } \\
\text { an Mandiri }\end{array}$ & $\begin{array}{l}\text { Tahapan ini pada prinsipnya sama dengan refleksi pertama dan } \\
\text { kedua. Hanya saja, intervensi supervisor semakin kecil karena } \\
\text { kapasitas supervee sudah berkembang dengan baik. Supervisor } \\
\text { lebih banyak memotivasi dan menguatkan serta menya-kinkan } \\
\text { kemampuan supervee. Alternatif- alternatif perbaikan dari masalah } \\
\text { yang ada tetap mejadi bagian dari tujuan refleksi. Demikian halnya } \\
\text { penguatan dan pengayaan kemampuan mengajar tetap menjadi } \\
\text { bagian penting dalam refleksi. }\end{array}$ & $\begin{array}{l}\text { Catatan/ } \\
\text { hasil } \\
\text { pemot- } \\
\text { retan atau } \\
\text { hasil } \\
\text { rekaman }\end{array}$ \\
\hline $\begin{array}{l}\text { Perayaan/ } \\
\text { selebrasi }\end{array}$ & $\begin{array}{l}\text { Tahap berikutnya, dilakukan penguatan terhadap keberhasilan guru } \\
\text { melalui proses supervisi. Sekecil apapun perubahan ke arah yang } \\
\text { lebih baik bagi supervee perlu diapresiasi secara antuasias sebagai } \\
\text { bentuk keberhasilan. Oleh karena itu, dilakukan perayaan atau }\end{array}$ & Hadiah \\
\hline
\end{tabular}


selebrasi dengan memberi kesempatan kepada supervee mengemukakan kesan-kesan dan komitmen untuk melakukan yang terbaik dalam pembelajaran. Pada akhirnya, supervisor dapat memberikan reward berupa pujian, semangat yang luar biasa, dan dapat pula berupa buku yang berkaitan dengan pengembangan potensi diri.

\section{Monitoring dan evaluasi}

Tahap selanjutnya setelah guru/supervee dilepas secara mandiri di kelasnya kembali, maka kegiatan selanjutnya adalah memantau atau memonitoring dan mengevaluasi dampak supervisi akademik yang telah dilakukan. Kegiatan ini lebih diutamakan kemandirian supervee. Hal ini dimaksudkan agar kesadaran pentingnya mengembangkan kapasitas diri ditumbuhkan. Oleh karena itu, supervee diwajibkan membuat laporan perkembangan kemampuan mengajar melalui laporan evaluasi diri (LED) supervee dalam bentuk jurnal mengajar. Pemantauan sebaiknya dilakukan dalam selang waktu yang lama. LED supervee secara berkala setiap bulan untuk melihat perkembangan kemampuan secara objektif oleh supervee. Dengan demikian, kesadaran untuk meningkatkan diri sudah tumbuh. Peran supervisor terus mensupport supervee dalam meningkatkan kemampuan melakukan pembelajaran.

Keberhasilan supervisi akademik ini perlu disebarkan kepada guru lainnya sebagai bentuk penguatan eksistensi diri atau efikasi para supervee. Pada pertemuan guru dalam gugus, perkembangan hasil supervisi sebagai keberhasilan diinformasikan kepada seluruh guru sebagai bagian dari filosofi maju bersama dalam gugus. Pada pertemuan tersebut sebaiknya para supervee didaulat untuk memaparkan pengalaman mereka pada supervisi akademik yang telah dilalui sebagai bagian dari penyemangatan bersama dan bentuk afirmasi seluruh guru. Hal ini penting karena selama ini banyak kecenderungan pengawas berusahan mendorong guru dengan menunjukkan sisi kelemahan dalam bentuk kritik bahkan ancaman. Hal ini juga menjadi salah satu bentuk pembedayan guru dalam komunitas dalam gugus.

Alur supervisi di atas terus bergulir sesuai tuntutan perkebmbangan kemampuan mengajar guru. Jika tahapan dengan kategori tenrtentu sudah dapat ditingkatkan lagi maka dilakukan pengembangan kemampuan yang lebih tinggi lagi. Dengan demikian, pembinaan mengenai kemampuan mengajar guru terus dilakukan dan terpantau secara objektif.

\section{METODE PENELITIAN}

\section{Desain penelitian}

Penelitian ini menggunakan metode penelitian eksperimen (eksperimen semu). Hal ini dilakukan dengan cara membandingkan tingkat kemampuan mengajar guru di SD gugus IV Kecamatan Makassar Kota Makassar. Desain analisis dalam penelitian ini adalah the one group pretest-posttest design dengan desain tersebut adalah sebagai berikut.

\begin{tabular}{ccc}
\hline 01 & $\mathrm{X}$ & 02 \\
\hline Pretes & Treatment & Postes \\
\hline
\end{tabular}

\section{Variabel penelitian}

Penelitian ini berupaya mengungkap dua variabel yakni penerapan supervisi akademik berbasis modeling inspiratif sebagai variabel bebas (X) dan tingkat kemampuan mengajar guru SD gugus IV Kecamatan Makassar Kota Makassar sebagai variabel terikat (Y). Secara operasional variabel bebas yang dimaksud adalah penerapan supervisi akademik berbasis modeling inspiratif terhadap guru/objek yang pada praktiknya supervisi menggunakan guru model sebagai inspirasi dalam mengembangkan kemampuan melaksanakan pembelajaran. Sedangkan variabel terikat adalah nilai kemampuan mengajar sebagai hasil supervisi akademik berbasis modeling inspiratif yang diperoleh dari observasi kemampuan mengajar guru.

\section{Populasi dan sampel}

Populasi atau subjek dalam penelitian ini adalah seluruh guru SD gugus IV Kecamatan 
Makassar Kota Makassar tahun pelajaran 2016/2017. Populasi tersebut berjumlah 62 orang yang terbagi dalam enam sekolah. Sesuai dengan karakterisktik penelitian dan jumlah subjek penelitian tidak terlalu banyak, maka seluruh populasi dijadikan subjek penelitian (total Sampling).

\section{Teknik Pengumpulan Data}

Data dikumpulkan melalui teknik obsevasi yaitu hasil kemapuan mengajar guru sebelum dan sesudah penerapan supervisi akademik berbasis modeling inspiratif di SD gugus IV Kecamatan Makassar, Kota Makassar.

Adapun tahapan dalam mengumpulkan data yang dilakukan dengan beberapa tahap utama yaitu:

1. Pengukuran tingkat kemampuan mengajar guru sebelum penerapan supervisi akademik berbasis modeling inspiratif melalui observasi.

2. Treatment berupa penerapan supervisi akademik berbasis modeling inspiratif.

3. Pengukuran tingkat kemampuan mengajar guru melalui observasi setelah penerapan supervisi akademik berbasis modeling inspiratif

4. Analisis data tingkat kemampuan mengajar guru sebelum dan sesudah penerapan supervisi akademik berbasis modeling inspiratif.

\section{Teknik analisis data}

Teknik analisis data adalah perhitungan statistik inferensial dengan analisis Uji-t Berpasangan (Paired Sample T-test) dengan SPSS versi 23.00 (Sugiyono, 2014) dengan menguji hipotesis sebagai berikut.

- $\mathrm{H}_{0}$ : tidak ada perbedaan signifikan kemampuan mengajar guru sebelum dan sesudah penerapan penerapan supervisi akademik berbasis modeling inspiratif.

- $\mathrm{H}_{1}$ : terdapat perbedaan signifikan kemampuan mengajar guru sebelum dan sesudah penerapan penerapan supervisi akademik berbasis modeling inspiratif.

\section{Kreteria:}

- Jika Sig. $\geq 0,05$ maka $\mathrm{H}_{0}$ diterima

- Jika Sig. $<0,05$ maka $\mathrm{H}_{0}$ ditolak

\section{HASIL PENELITIAN}

\section{Sajian data hasil penelitian}

a. Perbandingan tingkat kemampuan mengajar guru

Perbandingan tingkat kemampuan mengajar guru sebelum penerpan penerapan supervisi akademik berbasis modeling inspiratif dapat dilihat pada output analisis SPSS sebagai berikut.

Paired Samples Statistics

\begin{tabular}{|c|c|c|c|c|c|}
\hline & & Mean & $\mathrm{N}$ & Std. Deviation & Std. Error Mean \\
\hline \multirow[t]{2}{*}{ Pair 1} & Pra & 64,6068 & 62 & 8,12001 & 1,03124 \\
\hline & post & 73,6124 & 62 & 8,65244 & 1,09886 \\
\hline
\end{tabular}

Perbedaan nilai rata-rata setelah penerapan supervisi akademik berbasis modeling inspiratif lebih besar daripada rata-rata nilai sebelum yakni $(73,6124>64,6068)$, sedangkan hasil uji t pada Paired Samples Test menunjukkan ouput sebagai berikut.

Paired Samples Test

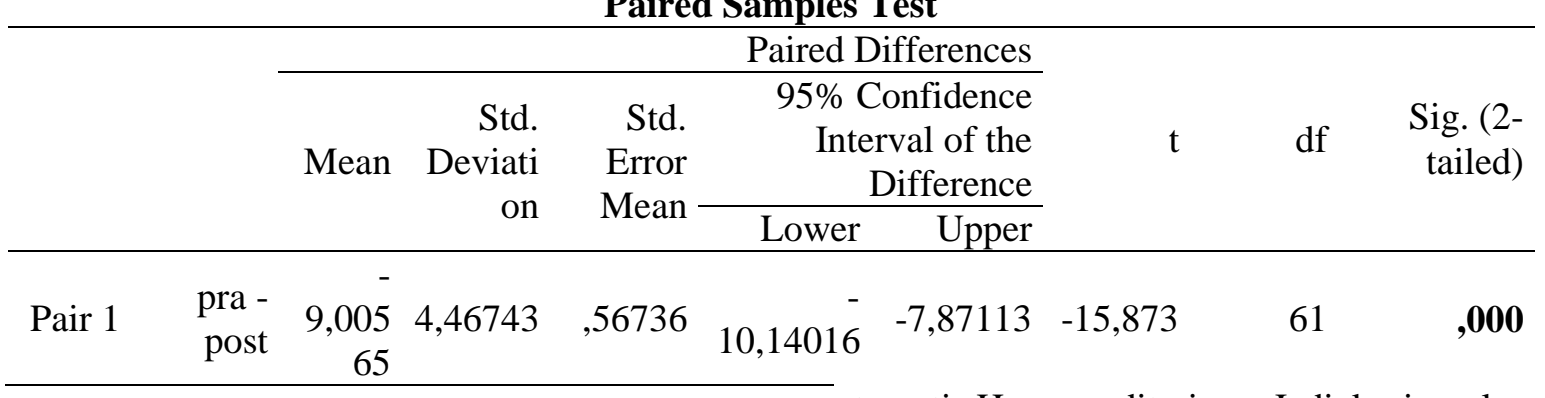

Hasil analisis menunjukkan bahwa nilai signifikansi. 0,000 lebih kecil daripada 0,05 maka artinya $\mathrm{H}_{0}$ ditolak, dan secara otomatis $\mathrm{H}_{1}$ yang diterima. Jadi kesimpulannya adalah hasil penelitian menunjukkan bahwa ada perbedaan yang signifikan antara kemampuan mengajar guru sebelum dan sesudah penerapan 
supervisi akademik berbasis modeling inspiratif. Hal ini menunjukkan bahawa penerapan supervisi akademik berbasis modeling inspiratif efektif dalam meningkatkan kemampuan mengajar guru SD Gugus IV Kecamatan Makassar Kota Makassar.

\section{Respon guru}

Respon guru terhadap kegiatan penerapan supervisi akademik berbasis modeling inspiratif, dijaring melalui angket yang diedarkan kepada guru menunjukkan bahwa dari 62 orang guru, $58,06 \%$ guru menyatakan sangat setuju penerapan supervisi akademik berbasis modeling inspiratif menarik, 41,94\%, menyatakan setuju, $0 \%$ menyatakan tidak ada pendapat, $0 \%$ menyatakan tidak setuju, dan $0 \%$ menyatakan sangat tidak setuju. Dari segi kemudahan, 61,29\% guru menyatakan sangat setuju kegiatan penerapan supervisi akademik berbasis modeling inspiratif memudahkan, $38,71 \%$ guru menyatakan setuju, $0 \%$ menyatakan tidak ada pendapat, $0 \%$ menyatakan tidak setuju, dan $0 \%$ menyatakan sangat tidak setuju. Dari segi kebermanfaatan, 59,68\% guru menyatakan sangat setuju kegiatan penerapan supervisi akademik berbasis modeling inspiratif bemanfaat, 40,32\%, menyatakan setuju, $0 \%$ menyatakan tidak ada pendapat, $0 \%$ menyatakan tidak setuju, dan $0 \%$ menyatakan sangat tidak setuju. Dari segi perbandingan dengan cara lain, $53,23 \%$ guru menyatakan sangat setuju kegiatan penerapan supervisi akademik berbasis modeling inspiratif lebih baik dari cari lain, $46,77 \%$, menyatakan setuju, $0 \%$ menyatakan tidak ada pendapat, $0 \%$ menyatakan tidak setuju, dan 0\% menyatakan sangat tidak setuju. Dari segi kelanjutan, 62,90\% guru menyatakan sangat setuju kegiatan penerapan supervisi akademik berbasis modeling inspiratif lebih baik dari cari lain, 37,10\%, menyatakan setuju, 0\% menyatakan tidak ada pendapat, $0 \%$ menyatakan tidak setuju, dan $0 \%$ menyatakan sangat tidak setuju. Dari segi kebermaknaan, 66,13\% guru menyatakan sangat setuju kegiatan penerapan supervisi akademik berbasis modeling inspiratif bermakna, 33,87\%, menyatakan setuju, 0\% menyatakan tidak ada pendapat, $0 \%$ menyatakan tidak setuju, dan $0 \%$ menyatakan sangat tidak setuju.

Berdasarkan hasil analisis data di tersebut, dapat disimpulkan bahwa penerapan supervisi akademik berbasis modeling inspiratif mendapat respon yang sangat positif dari guru-guru SD Gugus IV Kecamatan Makassar, Kota Makassar sehingga penggunaannya dapat dinyatakan efektif.

\section{Pembahasan}

Berdasarkan hasil analisis data tarsebut dapat dinyatakan bahwa terdapat perbedaan signifikan antara nilai kemampuan mengajar guru sebelum dan sesuadah penerapan supervisi akademik berbasis modeling inspiratif. Hal ini menunjukkan bahawa penerapan supervisi akademik berbasis modeling inspiratif dinyatakan efektif meningkatkan kemam[uan mengajar guru khususnya di SD Gugus IV Kecamatan Makassar Kota Makassar. Hasil analisis data respon guru menunjukkan bahwa penerapan supervisi akademik berbasis modeling inspiratif mendapat respon yang sangat positif dari guru-guru SD Gugus IV Kecamatan Makassar, Kota Makassar.

Hasil penerapan penerapan supervisi akademik berbasis modeling inspiratif sesuai dengan konsep metode inspiratif bahwa salah satu cara efektif mengembangkan keterampilan tertentu adalah menekan sesorang untuk berhasil tetapi tidak membebani melainkan menginspirasi (Rehazh, 2011:21). Hal ini sejalan dengan pandangan Zakiyah (2009) bahwa ketekunan dalam mencapai target adalah kunci, tetapi kukuatannya ada pada contoh yang dapat mendorong seseorang mengikutinya. Hal yang senada ditegaskan oleh Jone (2012) bahwa inpirasi menjadi jembatan mulus sesorang menempuh proses kreatif dengan tanpa beban karena dorongan kuat keinginan menyamai model yang dilihatnya. Pandangan senada oleh Hervan (2007) bahwa pembinaan guru harus menempuh proses kreatif ibarat memegang burung pipit, jika digenggam kuat maka akan mati tercekik, tetapi jika dipegang longgar akan terbang meinggalkan niat baik para pembina.

Penerapan supervisi akademik berbasis modeling inspiratif dipahami sebagai suatu rangkaian proses yang membantu para guru dalam belajar berinteraksi bersama guru lain untuk mewujudkan tujuan spesifik yang telah ditargetkan adalah sebuah kebanaran. Kewenangan guru/pembimbing/mentor, pembelajaran kooperatif lebih bersifat direktif jika 
dibandingkan dengan pembelajaran kolaboratif karena kontrol secara ketat yang dilakukan oleh guru/mentor. Johnsons (2002) menyatakan sekurang-kurangnya terdapat lima unsur dasar agar dalam suatu kelompok terjadi pembelajaran kooperatif/kolaboratif, yaitu saling ketergantungan positif, pertanggungajawaban individu, keterampilan berkolaborasi, dan keefektifan proses kelompok.

\section{SIMPULAN DAN SARAN}

Berdasarkan data hasil penelitian, maka dapat dikemukakan beberapa kesimpulan sebagai berikut (a) Penerapan supervisi akademik berbasis modeling inspiratif efektif meningkatkan kemampuan mengajar guru SD gugus IV Kecamatan Makassar Kota Makassar. Hal ini terlihat dari hasil kemampuan mengajar guru menunjukkan nilai signifikansi 0,000 lebih kecil daripada nilai 0,05 . (b) Penerapan supervisi akademik berbasis modeling inspiratif mendapat respon sangat positif dari para guru SD gugus IV Kecamatan Makassar Kota Makassar.

\section{DAFTAR RUJUKAN}

Amani, Luh, dlk. 2013. "Implementasi Supervisi Klinis dalam Rangka Meningkatkan kemampuan guru mengelola pembelajaran pada guru SD segugus VII Kecamatan Sawan”. Jurnal Jurusan Pendidikan Dasar Program Studi Pendidikan Dasar, Program Pascasarjana Universitas Pendidikan Ganesha. Volume 3 Tahun 2013.

Dahar, R.W. 2012. Teori-teori Belajar. Jakarta: . Proyek Pengembangan LPTK: Jakarta

Dzaki, Muhammad Faiq. 2011. Teori Bandura Tentang Pemodelan (Pemodelan). Jakarta: Pustaka Media

Goldhammer, R. 2011. Clinical supervision: Special methods for the supervision of teachers. New York: Hlot, Rinehart and Winston.

Gurnam, Kaur Sidhu. 2012. "Formative Supervision of Teaching and Learning: Issues and Concerns for the School Head". European Journal of Scientific ISSN 1450-216X Vol.39 No.4 (2012). Diakses: 11 Agustus 2016, jam 19:30

Hervan, Agus. 2007. Sukses Membina Guru. Jakarta: Alfabetagrup
Johnson, Elaine B. 2002. Contextual Teaching and Learning. California: Corwin Press

Jone Stoke, 2012. Inspirasi Sukses (terjemahan) . Yogyakarta: Bentang

Junaid, Muhammad. 2011. "Pelaksanaan Supervisi Pembelajaran pada Sekolah Unggulan di Kota Makssar".Tesis. UNM Makassar

Komariah, Aan. 2011. "Melaksanakan Supervisi Akademis Melalui Penelitian Tindakan Sekolah (School Action Research)".

http://jurnal.upi.edu/penelitianpendidikan/ vol. 9 no.2, oktober 2011. Diakses: 11 Agustus 2016, jam 21:15

Kompas, 7

Maret 2012 ,

Kualitas.Guru.Masih.Rendah edukasi.kompas.com

Linda Lee-Davis.(2011), Developing Work and Study Skill, London: Thomson Learning.

Purwanto, M. Ngalim. 2013 Administrasi dan Supervisi Pendidikan. Bandung: PT Remaja Rosdakarya.

Rachel, Kershaw. 2013 "Social Learning Theory". Dalam: ." https://prezi.com. Diakses: 19 Oktober Agustus 2016, jam 10.10

Rehazh, 2011. Successfully Tim Work. New York: Alfapress

Ruhayati, Yati, dkk. 2013 .Kontribusi Layanan Supervisi, Kepemimpinan Kepala Sekolah, Dan Fasilitas Pembelajaran Terhadap Kinerja Guru Pendidikan Jasmani SMPN Se Kota Cimahi dalam http://jurnal.upi.edu.penelitianpendidikan/ vol.9 no.2, oktober 2013. Diakses: 11 Agustus 2016, Jam 19.10

Sahertian, Piet A. 2011. Konsep Dasar \& Teknik Supervisi Pendidikan dalam Rangka Pengembangan Sumber Daya Manusia. Jakarta: PT Rineka Cipta.

Setiyono, Imam . 2013. "Supervisi Pendidikan Sekolah Dasar". Jurnal Pendidikan Dasar, VOL. 6, NO.1, 2013. 1 - 60 Diakses: 11 Agustus 2016, Jam 19.10

Syukri. 2012 "Hubungan antara Peran Supervisi Pengawas Pendidikan Agama Islam Dengan Kualitas Pembelajaran Guru Mata Pelajaran Agama". http://jurnal.upi.edu.penelitianpendidikan/ vol. 9 no.2, oktober 2012. Diakses: 11Agustus 2016

Undang-undang No 14 Tahun 2005 tentang guru dan dosen. 
Unruh, A., \& Turner, H. E. 2011. Supervision for change and innovation. Boston: Houghton-Mifflin.

Zakiyah, Mihana. 2009. Kunci Sukses Menuai Target. Jakarta; Gema Press. 